\title{
Fracture Toughness and Strength of Bamboo-Fiber Reinforced Laterite as Building Block Material
}

\author{
F.O. Kolawole ${ }^{1, *}$, O.M. Olugbemi ${ }^{1}$, S.K. Kolawole ${ }^{2}$, A.F. Owa ${ }^{1}$, E.S. Ajayi ${ }^{3}$ \\ ${ }^{1}$ Department of Materials and Metallurgical Engineering, Federal University Oye-Ekiti, Nigeria \\ ${ }^{2}$ National Agency for Science and Engineering Infrastructure, Nigeria \\ ${ }^{3}$ Department of Agricultural and Bioresources Engineering, Federal University Oye-Ekiti, Nigeria
}

Copyright $\bigcirc 2017$ by authors, all rights reserved. Authors agree that this article remains permanently open access under the terms of the Creative Commons Attribution License 4.0 International License

\begin{abstract}
Modern day building materials must be sustainable, cheap, environmental friendly, durable and available. Laterite reinforced with bamboo fiber was moulded into blocks to determine the compressive strength, flexural strength and fracture toughness using universal tensile machine (UTM), while the elemental composition was determined by EDS, SEM/Gwyddion software were used to study the fractured surface of the bamboo-fiber reinforced laterite (BFRL) block. Water absorption test and bulk density were also carried out. The blocks were moulded by varying the percent weight (\%wt) fraction of bamboo fiber from 0 to $25 \%$. The dimensions for the compressive and flexural samples were $100 \times 100 \times 100 \mathrm{~mm}$ and $600 \times 100 \times$ $100 \mathrm{~mm}$ respectively. The results of the experiment showed that at $25 \%$ wt of bamboo fiber a maximum compressive strength, flexural strength and fracture toughness of 5.0 \pm 0.25 $\mathrm{MPa}, 2.25 \pm 0.113 \mathrm{MPa}$ and $1.70 \pm 0.085 \mathrm{MPa} \sqrt{m}$ respectively were obtained. EDS result reviewed the following elements $\mathrm{Al}, \mathrm{Si}, \mathrm{Ca}, \mathrm{Fe}$ and $\mathrm{C}$. SEM images analyzed using Gwyddion software reviewed different fracture patterns.
\end{abstract}

Keywords Bamboo, Blocks, Cement, Compressive Strength, Fracture Toughness, Fibers, Laterite, Reinforcement

\section{Introduction}

Building materials has evolved over time and a variety of them has been used from the early days till now [1-3]. Materials used for building must be cheap, require less energy, environmental friendly, readily available and possess excellent mechanical properties [4-9]. Cement, clay and laterite [10-12] has been used in the production of blocks for building materials till this present time. Cement used for building blocks has some advantages such as high bulk density, low water absorption, good binding properties, good compressive and fracture strength, but also has disadvantages such as high cost of production, $\mathrm{CO}_{2}$ emission, high energy consumption and heavy weight [11-15]. Sustainability in building materials is very important and can also be achieved through the use of local materials [4-11]. Laterite is a local material which is readily available, environmentally friendly and cheap [10-13]. The use of laterite in the production of building blocks has been dated as far back as 1000 CE, [16] and is still currently used in the rural areas. The main challenge faced by the use of laterite as building block is that of cracks, because of the brittle nature of the laterite blocks. Fibers as reinforcement in laterite blocks have been used in recent times to improve compressive, flexural strength and fracture toughness [17-20]. A wide range of fibers has been used to reinforce laterite blocks such as straws, saw dust, wood, rice husk, coconut shell, sisal, leaves of different plants [11, 17, 19, 21, 22]. The use of bamboo fibers for laterite blocks would have several advantages such as; high yield strength, high elastic modulus, light weight and due to the unique properties of bamboo [23-26]. Composite used as building blocks would ensure light weight, fracture toughness, high compressive strength and improved tensile strength compared to laterite blocks without reinforcement [23-24]. This study seeks to address the use of varying weight fraction of bamboo fibers to reinforce laterite-cement matrix and to determine the compressive strength, flexural strength, fracture toughness, water absorption properties and bulk density. Also to examine the structure and morphology of the bamboo fiber reinforced laterite (BFRL) block.

\section{Materials and Methods}

The experimental materials used in this study were bamboo sticks, cement and laterite soils, which were obtained from Oke-Ayedun, Ekiti State, Nigeria and cement $(25 \mathrm{~kg})$ was obtained from an outlet in Ikole-Ekiti, Ekiti State, Nigeria, while Sodium hydroxide (500 g) was obtained from 
Lagos, Nigeria.

\section{Sample Preparation}

Bamboo sticks were mechanically milled to small pieces using a mortar, after which the bamboo fibers obtained were, soaked in sodium hydroxide for 9 hours; this was to allow for removal of lignin content, so as to provide proper interfacial bonding between the matrix and the fibers. Thereafter, the bamboo fibers were dried in the sun for a period of 14 days to allow complete removal of water. Laterite sand was dug from Oke-Ayedun, a small town in Ekiti State and was dried for 3 days; thereafter the lumps were broken into small pieces and sieved using a sieve size of $150 \mu \mathrm{m}$. Wooden moulds were made of dimensions $100 \times 100 \times 100 \mathrm{~mm}$ and $600 \times 100 \times 100 \mathrm{~mm}$ for compressive and flexural samples respectively.

Table 1. Laterite - Cement Matrix

\begin{tabular}{|c|c|c|}
\hline Sample & Laterite (\% weight) & Cement (\% weight) \\
\hline I & 80 & 20 \\
\hline
\end{tabular}

Table 2. Laterite - Cement Matrix with varying Weight (\%) of Bamboo Fiber

\begin{tabular}{|c|c|c|}
\hline Samples & $\begin{array}{c}\text { Laterite + Cement (\% } \\
\text { weight) }\end{array}$ & $\begin{array}{c}\text { Bamboo Fiber (\% } \\
\text { weight) }\end{array}$ \\
\hline I & 95 & 5 \\
\hline II & 90 & 10 \\
\hline III & 85 & 15 \\
\hline IV & 80 & 20 \\
\hline V & 75 & 25 \\
\hline
\end{tabular}

In this work, the matrix composition was a mixture of laterite ( $80 \%$ wt) and cement (20\% wt) (table 1). Blocks were then moulded by varying the bamboo fibers (\%wt) from 5 to $25 \%$ (table 2) and adding appropriate amount of water, while those without bamboo fiber served as control samples. All samples were sun dried for 14 days before carrying out any test; this was to allow the samples enough time to cure, because of the cement contained in them.

\section{Mechanical Test}

Compressive and flexural strength were determined by a digital compression/bending universal testing machine (UTM). The samples used for compressive test were moulded to dimensions of $100 \times 100 \times 100 \mathrm{~mm}$, while those for flexural test were moulded to dimensions of $600 \mathrm{x} 100 \mathrm{x}$ $100 \mathrm{~mm}$.

$$
\begin{gathered}
\text { Compressivestrength }=\frac{\text { MaximumLoadApplied }(N)}{\operatorname{Area}\left(\mathrm{mm}^{2}\right)}=\frac{F}{A}(1) \\
\text { Flexuralstrength }\left(\delta_{f}\right)=\frac{3 F L}{2 B D^{2}}
\end{gathered}
$$

Where $\mathrm{F}$ is the applied load $(\mathrm{KN}), \mathrm{L}$ is the length of sample, $\mathrm{B}$ is the breadth of sample, $\mathrm{D}$ is the thickness of sample, A is the cross sectional area of sample

$$
\begin{gathered}
\text { Fracture toughness }\left(\mathrm{K}_{\mathrm{c}}\right)=Y \sigma \sqrt{\pi a} \\
\qquad \mathrm{Y}=f\left(\frac{a}{w}\right)
\end{gathered}
$$

Where $\mathrm{Y}$ is the function of crack length, $\mathrm{w}$ is the width of the specimen, $a$ is the total notch length

The geometry function for single edge notched bend (SENB) geometry as ASTM standard E399-81 is given by:

$$
Y=\left(\frac{a}{w}\right)=\frac{3\left(\frac{a}{w}\right)^{\frac{1}{2}}}{2\left(1+2 \frac{a}{w}\right)\left(1-\frac{a}{w}\right)^{\frac{3}{2}}} \times\left[1.99-\left(\frac{a}{w}\right)\left(1-\frac{a}{w}\right)\left(2.15-3.93 \frac{a}{w}+2.7 \frac{a^{2}}{w^{2}}\right)\right]
$$




\section{Water Absorption Test}

Water absorption test was carried out on the bamboo fiber reinforced laterite blocks by completely immersing the $100 \mathrm{x}$ $100 \times 100 \mathrm{~mm}$ block in water for 24 hours. The percentage water absorption was then calculated using the following formula:

$$
W=\frac{M_{2}-M_{1}}{M_{1}} \times 100 \%
$$

Where $\mathrm{W}$ is the water absorption (\%), $\mathrm{M}_{1}$ is the dry block, $\mathrm{M}_{2}$ is the wet block

\section{Bulk Density Determination}

The bulk densities of the bamboo fiber reinforced laterite blocks $(100 \times 100 \times 100 \mathrm{~mm})$ were estimated using the following formula:

$$
\rho=\frac{M}{V}
$$

$\rho$ is the bulk density, $\mathrm{M}$ is the mass (kg), $\mathrm{V}$ is the volume $\left(\mathrm{m}^{3}\right)$

\section{Characterization}

Optical images were taken using Proscope HR Microscope to study the morphology of the BFRL block. Scanning electron microscopy/Energy dispersion spectroscopy (SEM/EDS), Phenom ProX SEM with EDS was used to study the morphology, composition and structure of the BFRL blocks. SEM/EDS were carried out at Covenant University, Otta, Ogun state, Nigeria. Gwyddion software was also used to analyse the SEM images to study the nature of the fractured surfaces of the BFRL blocks.

\section{Results and Discussions}

\section{Compressive Strength}

The results of the compressive strength for BFRL blocks which were tested after drying for 14 days are as shown in table 3 and figure 1.

Table 3. Compressive Strength of Different Weight (\%) of Bamboo Fiber

\begin{tabular}{|c|c|c|c|}
\hline $\begin{array}{c}\text { Samp } \\
\text { les }\end{array}$ & $\begin{array}{c}\text { Bamboo Fiber } \\
\text { (\% weight) }\end{array}$ & $\begin{array}{c}\text { Max. Load } \\
(\mathrm{KN})\end{array}$ & $\begin{array}{c}\text { Compressive Strength } \\
\text { (MPa) }\end{array}$ \\
\hline I & 0 & 20 & $2.0 \pm 0.100$ \\
\hline II & 5 & 21 & $2.1 \pm 0.105$ \\
\hline III & 10 & 24 & $2.4 \pm 0.120$ \\
\hline IV & 15 & 25 & $2.5 \pm 0.125$ \\
\hline V & 20 & 31 & $3.1 \pm 0.155$ \\
\hline VI & 25 & 50 & $5.0 \pm 0.250$ \\
\hline
\end{tabular}

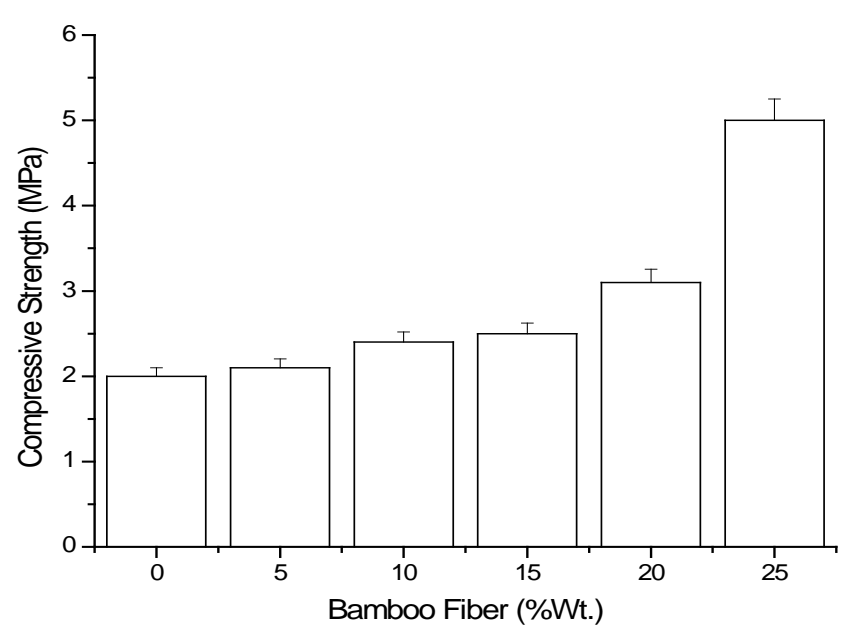

Figure 1. Compressive Strength of Varying Weight (\%) of Bamboo Fiber

The bar chart in figure 1 above shows a significant increase in compressive strength from $2.0 \pm 0.100$ to $5.0 \pm 0.250 \mathrm{Mpa}$ as the bamboo fibers (\%wt) increases from 0 to $25 \%$. The strength at $15 \%$ bamboo fiber addition is twice that of $25 \%$ bamboo fiber, the presence of the bamboo fibers helped to increase the resistance to breaking under compressive loading. The results obtained can be compared with similar work done by Morel, et al [27] and Kabiru, 2010 [28].

\section{Flexural Strength}

The table 4 shows the results of the flexural test of the BFRL samples with different bamboo fiber (\%wt).

Table 4. Flexural Strength of Different Weight (\%) of Bamboo Fiber

\begin{tabular}{|c|c|c|c|}
\hline Samples & $\begin{array}{c}\text { Bamboo Fiber } \\
\text { (\% weight) }\end{array}$ & $\begin{array}{c}\text { Flexural } \\
\text { Strength (Mpa) }\end{array}$ & $\begin{array}{c}\text { Fracture Toughness } \\
(\mathrm{Mpa} \sqrt{m})\end{array}$ \\
\hline I & 0 & $0.9 \pm 0.045$ & $0.68 \pm 0.034$ \\
\hline II & 5 & $1.17 \pm 0.056$ & $0.89 \pm 0.045$ \\
\hline III & 10 & $1.35 \pm 0.068$ & $1.02 \pm 0.051$ \\
\hline IV & 15 & $1.62 \pm 0.081$ & $1.23 \pm 0.062$ \\
\hline V & 20 & $1.80 \pm 0.090$ & $1.36 \pm 0.068$ \\
\hline VI & 25 & $2.25 \pm 0.113$ & $1.70 \pm 0.085$ \\
\hline
\end{tabular}

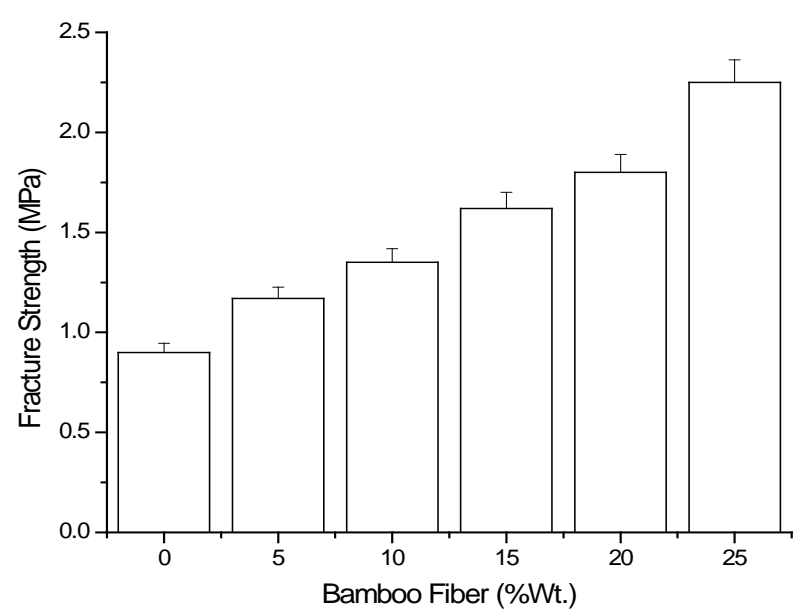

Figure 2. Flexural Strengthof Varying Weight (\%) of Bamboo Fiber 
The bar chart shows the flexural strength of the different composition of the bamboo fiber reinforced laterite sample (figure 2). The result obtained shows an increasing flexural strength as the weight fraction of bamboo fiber increases from 0 to $25 \%$. This is as a result of an increase in bamboo fibers which resist fracture in the laterite based block.

From the bar chart a maximum flexural strength of $2.25 \pm 0.113$ Mpa was obtained at 25\% bamboo fiber which can be compared to results obtained by Kalu, et al [19], while a minimum of $0.9 \pm 0.045$ Mpa was obtained at $0 \%$ bamboo fiber. The minimum flexural strength obtained was due to the absence of bamboo fibers and which fractured easily as shown in the SEM result (figure 7a). The increase in flexural strength in the BRFL samples as bamboo fiber was increased due to the ability of the bamboo fibers to arrest cracks that exist in the blocks and resist propagations of such cracks in such a way that the cracks cannot grow to critical length or may take longer time to propagate.

\section{Fracture Toughness}

Figure 3 shows a bar chart which represents the fracture toughness results of bamboo fiber reinforced laterite (BFRL) block.

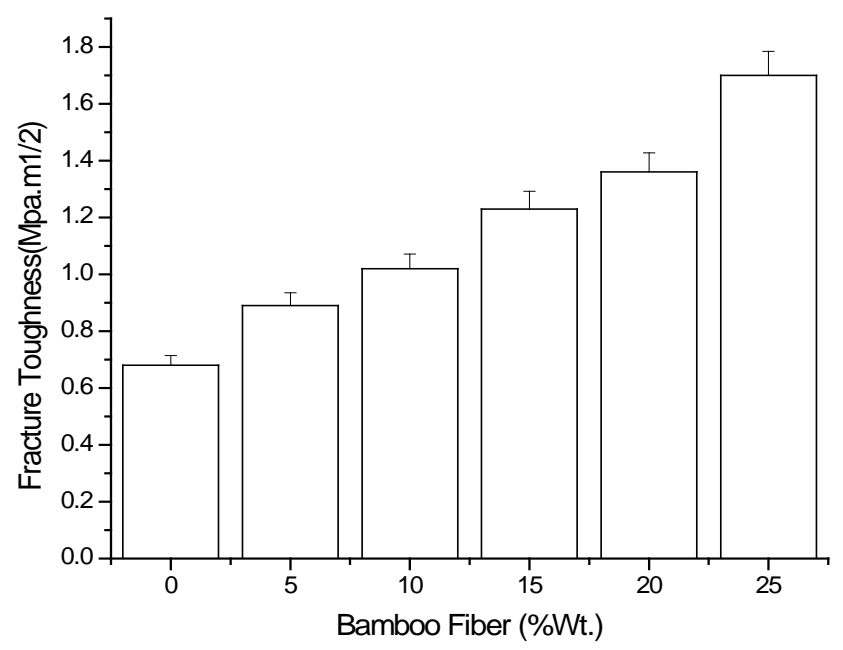

Figure 3. Fracture Toughness ofVaryingWeight (\%) of Bamboo Fiber

A minimum fracture toughness of $0.68 \pm 0.034 \mathrm{Mpa} \sqrt{\mathrm{m}}$ was obtained at $0 \%$ bamboo fiber, due to the absence of fibers to arrest crack. While for 5 to $25 \%$ bamboo fiber, an increase in fracture toughness was observed which was due to the ability of the bamboo fibers to arrest cracks, which also gives the block toughness. A maximum fracture toughness of $1.70 \pm 0.085 \mathrm{Mpa} \sqrt{\mathrm{m}}$ was observed at $25 \%$ bamboo fibers. Kabiru, in his study reported a fracture toughness of 1.21 to 2.0 Mpa $\sqrt{\mathrm{m}}_{\mathrm{m}}[28]$.

Fracture toughness in building blocks is very important to avoid sudden failure or facture. Reinforcing laterite-cement (brittle material) with bamboo fibers (ductile material) gives the block structure some level of ductility, therefore by increasing the bamboo fibers increase the tendency to arrest cracks in the material and improves the toughness property of the BFRL blocks.

\section{Water Absorption}

Figure 4 shows a plot of water absorption (\%) against bamboo fiber (\%wt).

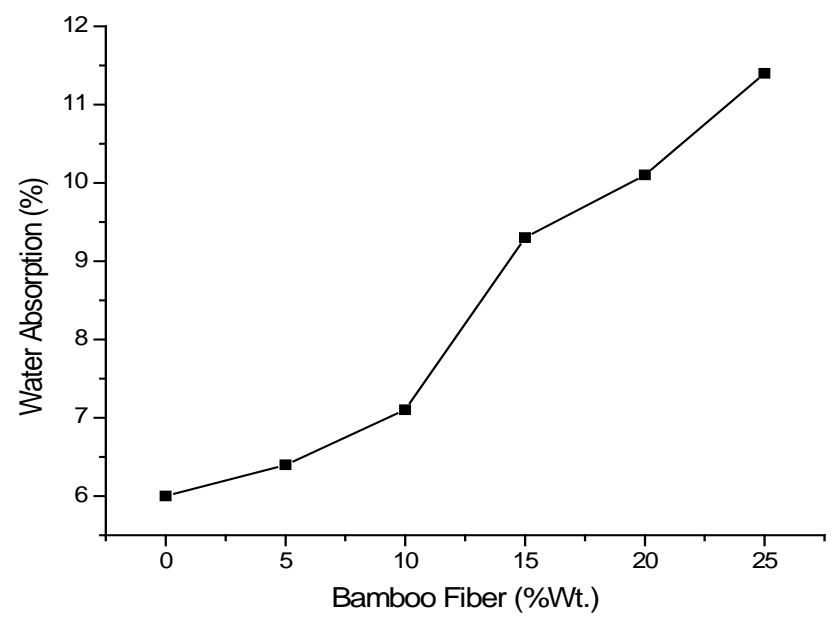

Figure 4. Water Absorption for Varying Weight (\%) of BFRL Blocks

Table 5. Water Absorption for Varying Weight (\%) of BFRL Blocks

\begin{tabular}{|c|c|c|c|c|}
\hline Samples & $\begin{array}{c}\text { Bamboo } \\
\text { Fiber }(\% \\
\text { weight })\end{array}$ & $\begin{array}{c}\text { Weight of } \\
\text { Dry Block } \\
(\mathrm{kg})\end{array}$ & $\begin{array}{c}\text { Weight of } \\
\text { Wet Block } \\
(\mathrm{kg})\end{array}$ & $\begin{array}{c}\text { Water } \\
\text { Absorption } \\
(\%)\end{array}$ \\
\hline I & 0 & 1.70 & 1.80 & 6.0 \\
\hline II & 5 & 1.63 & 1.73 & 6.4 \\
\hline III & 10 & 1.55 & 1.66 & 7.1 \\
\hline IV & 15 & 1.50 & 1.64 & 9.3 \\
\hline V & 20 & 1.42 & 1.56 & 10.1 \\
\hline VI & 25 & 1.37 & 1.53 & 11.4 \\
\hline
\end{tabular}

The result shows that there was an increase in water absorption from 6 to $11.4 \%$ as the bamboo fiber addition increased from 0 to $25 \%$. It shows that the samples without bamboo fibers had better resistance to water absorption, this was due to the nature of bamboo sticks to absorb water, and therefore as the bamboo fiber (\%wt) increases so does the tendency of the BF8RL block to absorb water increase also. However, the maximum acceptable standard for water absorption for building blocks in Nigeria according to the Nigerian Building and Road Research Institute (NBRRI) is $12.5 \%$ [11] and therefore the BFRL block falls within the acceptable range.

\section{Bulk Density}

The bulk densities which were estimated for the different samples are shown in figure 5 . It can be observed from the plot that there is a reduction in the trend of the bulk density of the BFRL samples as the bamboo fiber increases, this is as a result of the light weight of the bamboo fibers, therefore as 
the bamboo fibers increases the bulk density and the weight of the BFRL block reduces. From the plot the minimum and maximum bulk densities are estimated to be 1370 and 1700 $\mathrm{kg} / \mathrm{m}^{3}$ at 25 and $0 \%$ bamboo fiber respectively.

Table 6. Bulk Density for Varying Weight (\%) of BFRL Blocks

\begin{tabular}{|c|c|c|c|c|}
\hline Samples & $\begin{array}{c}\text { Bamboo } \\
\text { Fiber (\% } \\
\text { weight })\end{array}$ & $\begin{array}{c}\text { Weight of } \\
\text { Dry Block } \\
(\mathrm{kg})\end{array}$ & $\begin{array}{c}\text { Volume of } \\
\text { Dry Block } \\
\left(\mathrm{m}^{3}\right)\end{array}$ & $\begin{array}{c}\text { Bulk } \\
\text { Density } \\
\left(\mathrm{kg} / \mathrm{m}^{3}\right)\end{array}$ \\
\hline I & 0 & 1.70 & 0.001 & 1700 \\
\hline II & 5 & 1.63 & 0.001 & 1630 \\
\hline III & 10 & 1.55 & 0.001 & 1550 \\
\hline IV & 15 & 1.50 & 0.001 & 1500 \\
\hline V & 20 & 1.42 & 0.001 & 1420 \\
\hline VI & 25 & 1.37 & 0.001 & 1370 \\
\hline
\end{tabular}

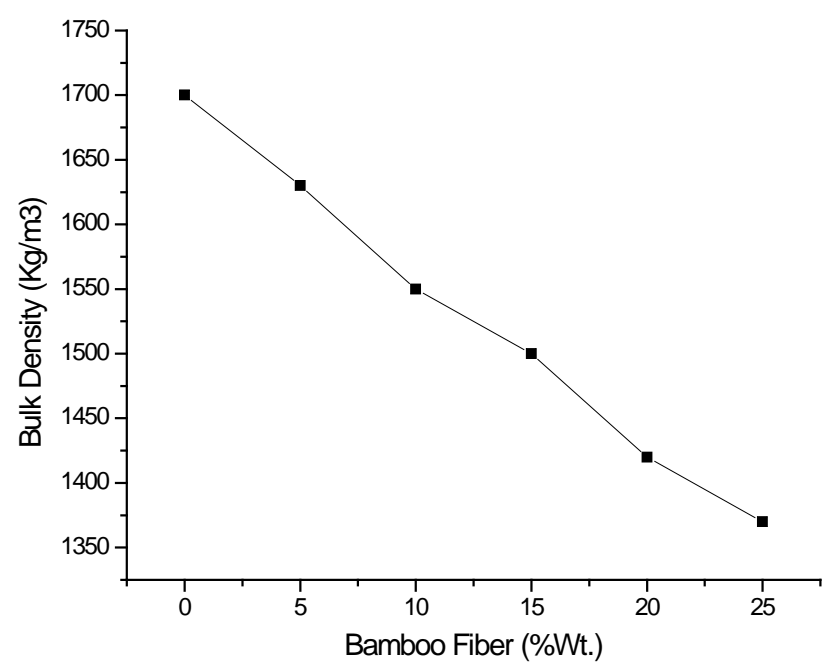

Figure 5. Bulk Density for Varying Weight (\%) of BFRL Blocks

\section{Elemental Composition}

The EDS analysis obtained from the BFRL block is shown in figure 6 and table 7 . The EDS result revealed trace elements present in the bamboo fiber-reinforced laterite

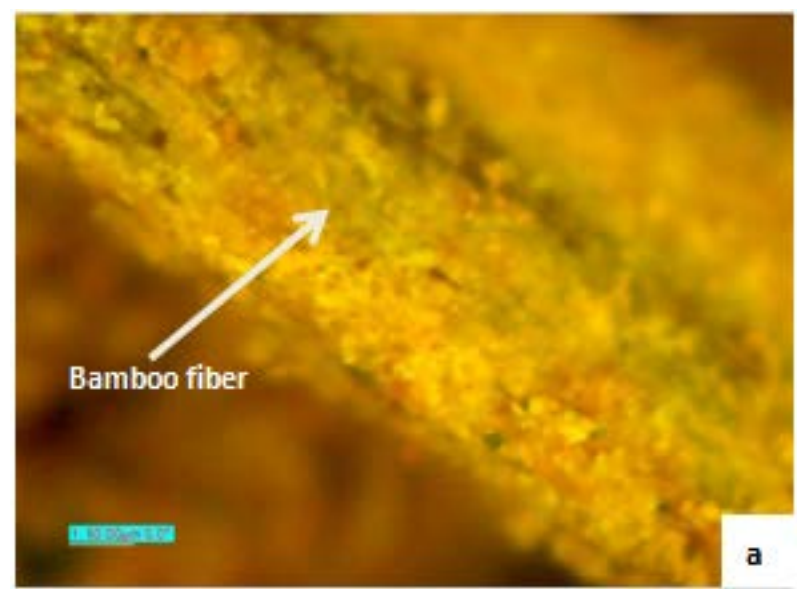

material. Trace elements such as $\mathrm{Al}, \mathrm{Si}$ and Fe were present and are commonly found in laterite sand. $\mathrm{Ca}$ and $\mathrm{C}$ are commonly found in cement, $\mathrm{C}$ can also be present in bamboo fibers which contain cellulose in them. All these elements present form compounds which are stable and provide a strong interfacial bonding between the laterite-cement matrix and the bamboo fiber, giving the composite the necessary strength and toughness required to resist crack propagation.

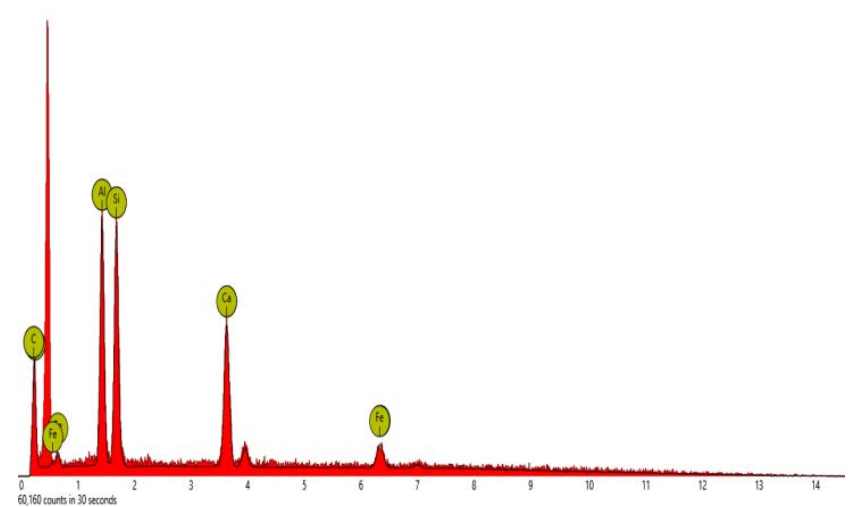

Figure 6. EDS analysis of Laterite-Cement with 25\% Bamboo Fiber

Table 7. Composition of Bamboo Fiber Reinforced Laterite Block

\begin{tabular}{|c|c|c|c|c|c|}
\hline Element (\%) & Al & Si & Ca & Fe & C \\
\hline $\begin{array}{c}\text { Bamboo Fiber } \\
\text { Reinforced } \\
\text { Laterite } \\
\text { Composite }\end{array}$ & 24.1 & 25.7 & 25.5 & 13.0 & 11.7 \\
\hline
\end{tabular}

\section{Optical Microscopy}

Optical microscope images of the structure and morphology of the laterite based material are presented in figure $7(a-c)$. Figure 7a reveals bamboo fiber in the laterite based material being fractured and figure $7 \mathrm{~b}$ shows rough surface of the laterite based material after being facture, while figure 7c reveals holes present in the laterite based material after fracture due to fiber pull-out from the surface of the laterite based material.

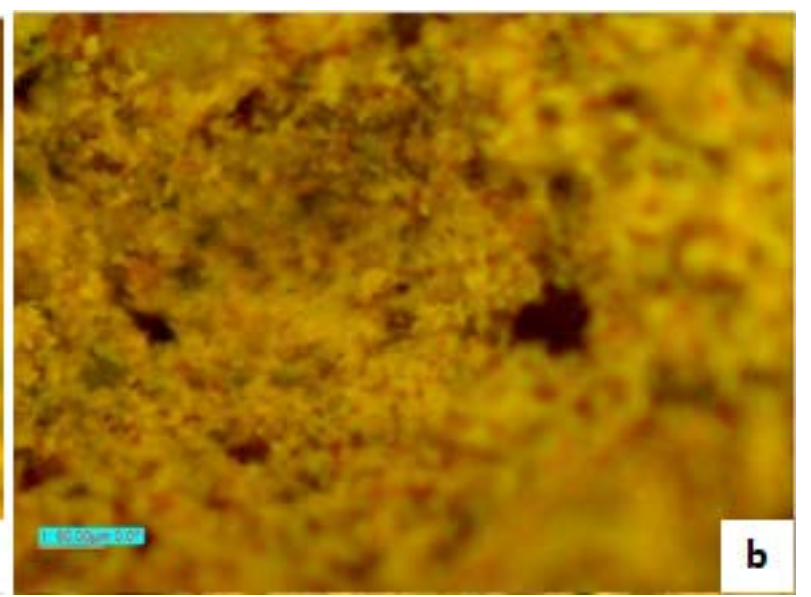




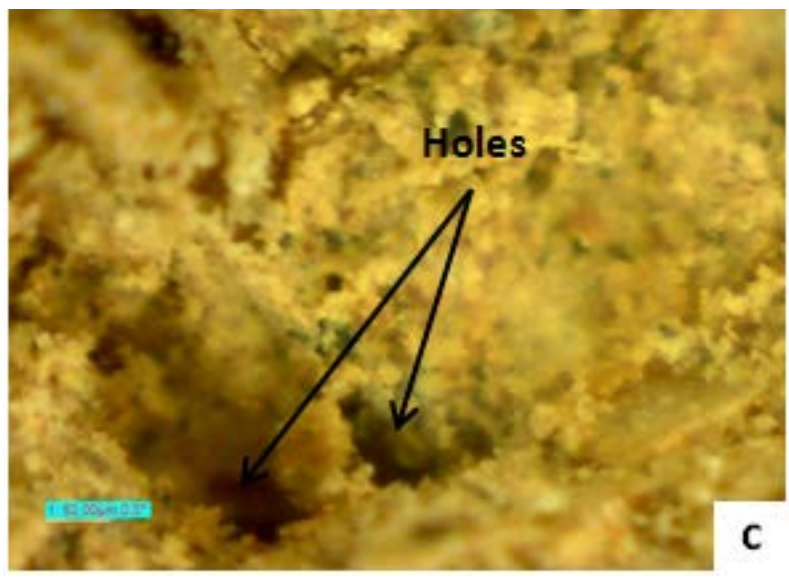

Figure 7. Optical Microscope Images of Laterite Based Material (a) bamboo fiber after fracture (b) Surface of laterite based material after fracture (c) holes generated as a result of fiber pull-out after fracture.

\section{Scanning Electron Microscopy}

Scanning Electron Microscope images of the structure and morphology of the different samples are presented in figure 8 (a - f). figure 8a shows SEM image of laterite and cement without bamboo fibers, the SEM image reveals a crack within the laterite based block, this was due to absence of fibers to resist propagation of crack growth as compared to figures 3 (b - f), which had no cracks propagating throughout the laterite based material, although cracks are present they may not be able to propagate throughout the laterite based material because of the bamboo fibers which are distributed in the matrix. These bamboo fibers help in arresting existing cracks and hinder their propagation. Hence, the fracture toughness improves as the percentage of bamboo fibers increases.
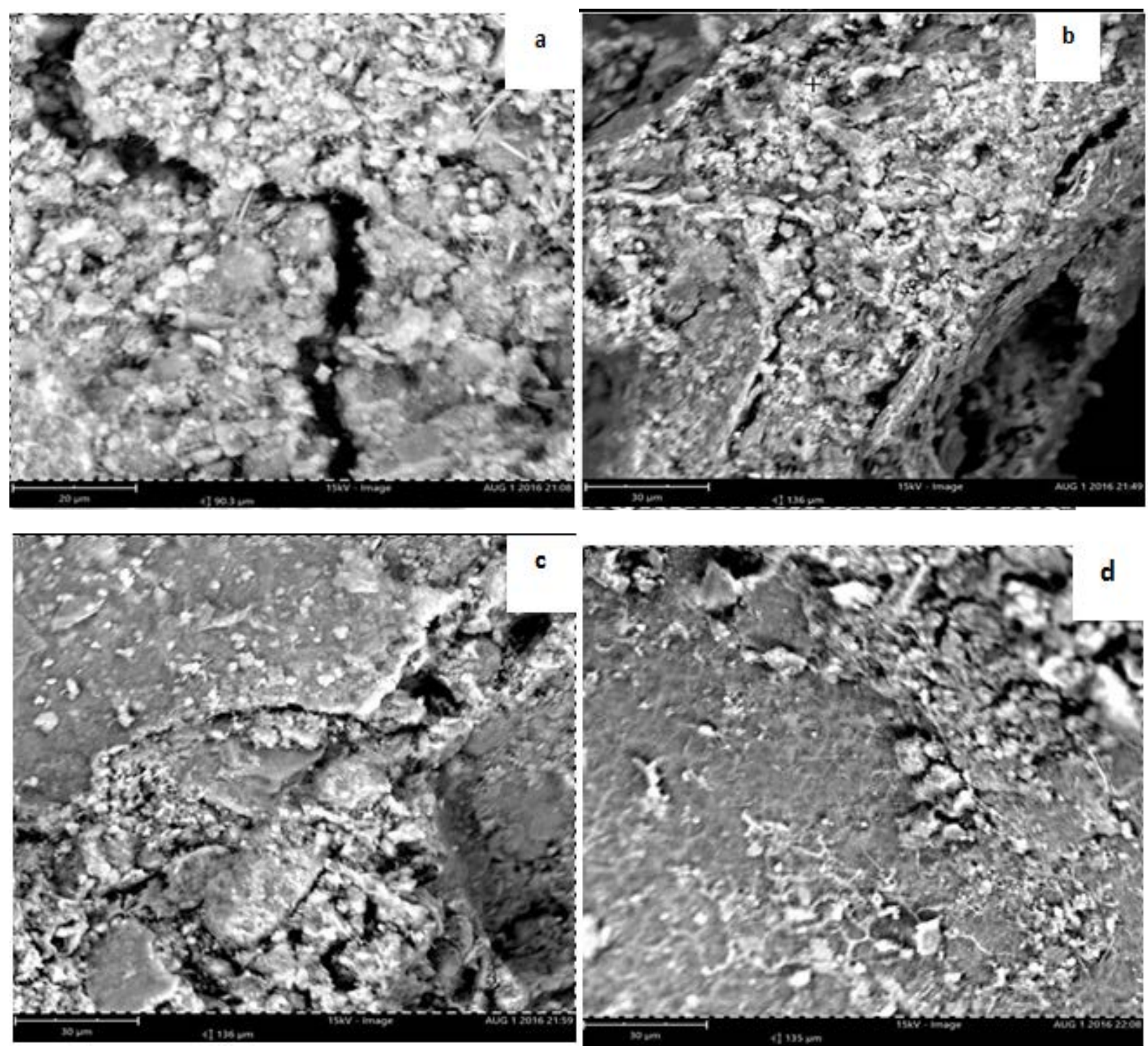

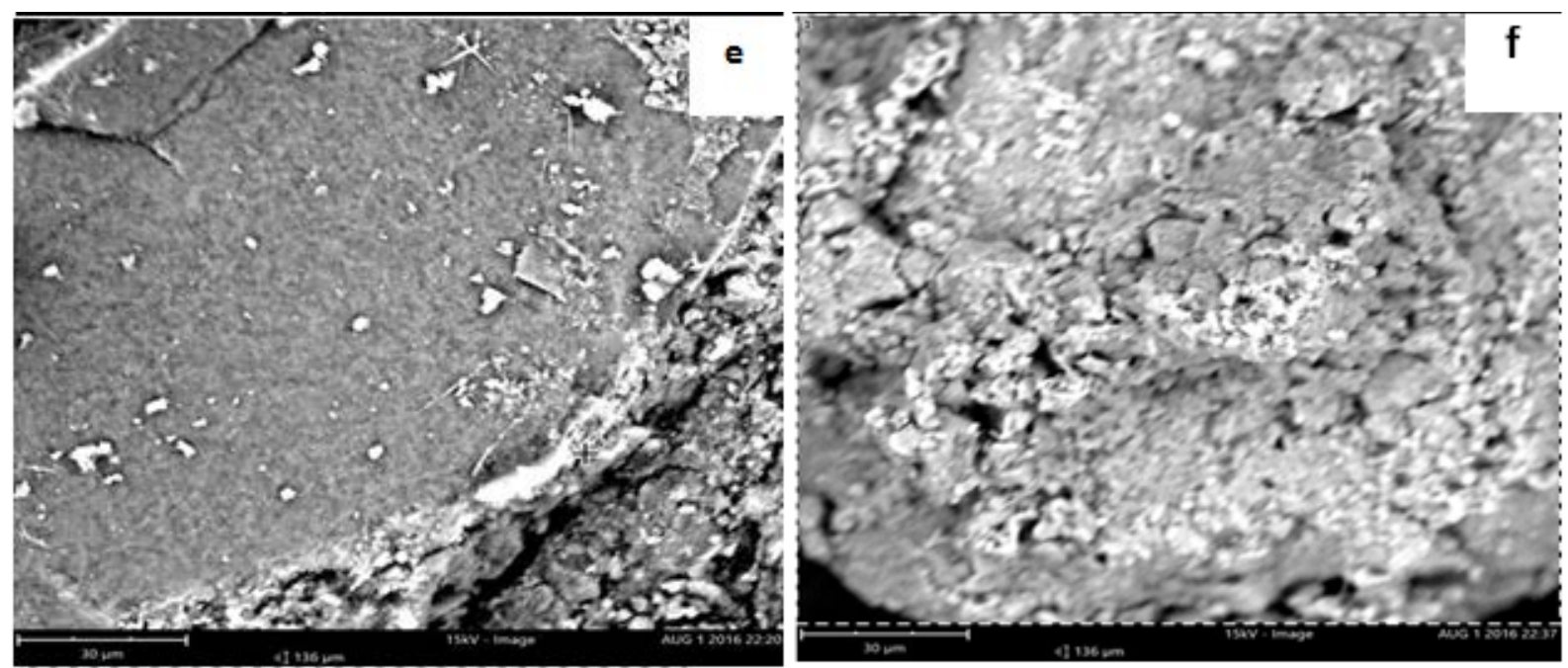

Figure 8. SEM Images of Laterite Based B (a) $0 \%$ bamboo fiber (b) $5 \%$ bamboo fiber (c) $10 \%$ bamboo fiber (d) $15 \%$ bamboo fiber (e) $20 \%$ bamboo fiber (f) $25 \%$ bamboo fiber.

\section{Fractured Surface}

Gwyddion Software was used to analyze SEM images of the laterite based material to study the pattern of the fractured surfaces. Figure 9 (a - f) shows the different pattern of fractured surfaces. Figure 9a shows a brittle fractured surface with a crack cutting across the entire sample; this is attributed to the absence of bamboo fibers which would hinder the entire sample from cracking one end to the other. Figure 9a, 9b and 9e shows a typical ductile fractured surface being characterized by a cup and cone shape, because the material is not metallic in nature it is not expected to undergo necking. For this type of materials the brittle fracture is characterized by a uniform and smooth surface (figure 9a), while ductile fracture is characterized by a non-uniform and rough surface (figure 9a, 9b and 9e). It is expected that there will be an increase in ductility as the volume percentage of bamboo fibers increases this is as a result of the increase in the resistance to crack propagation by the bamboo fibers.
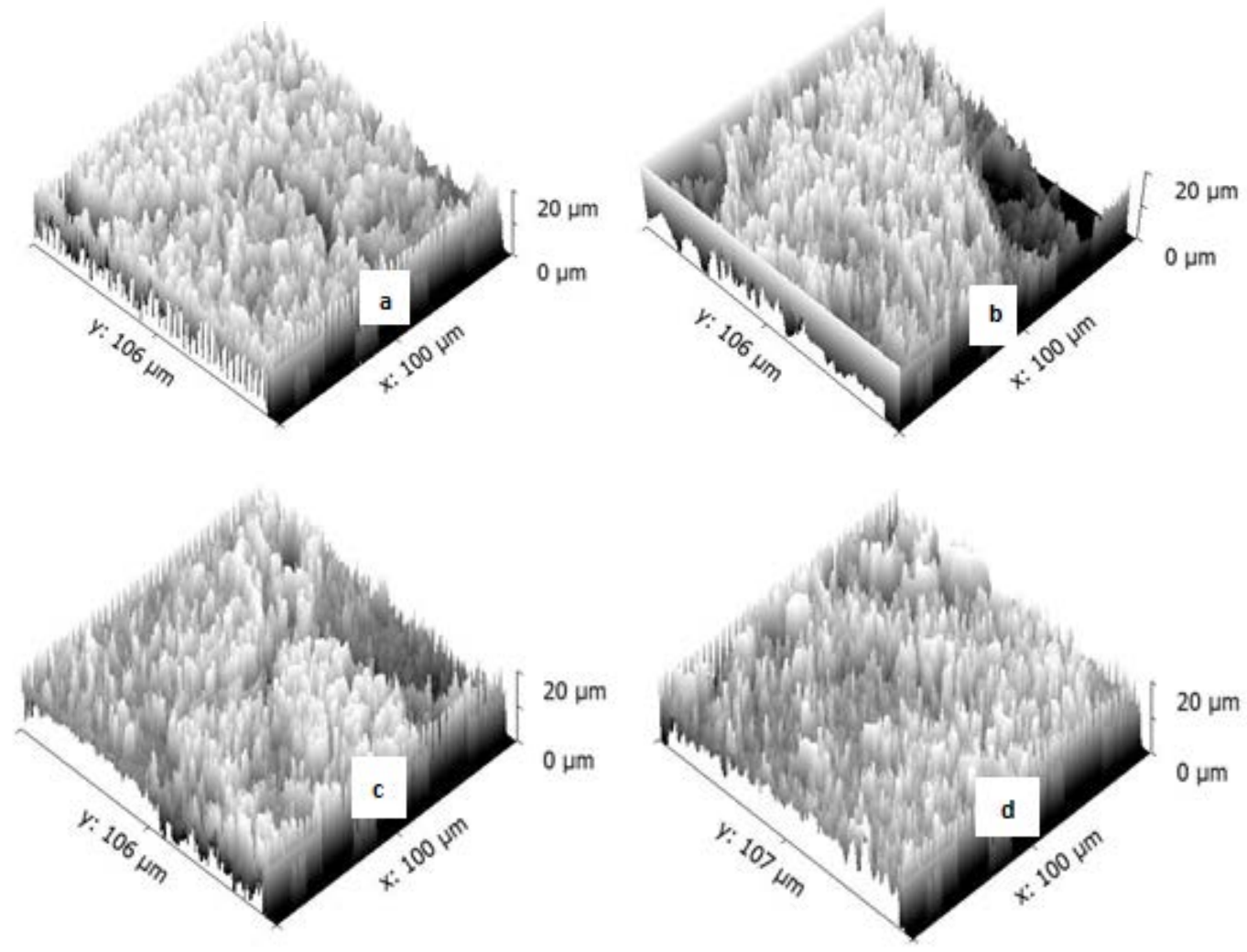

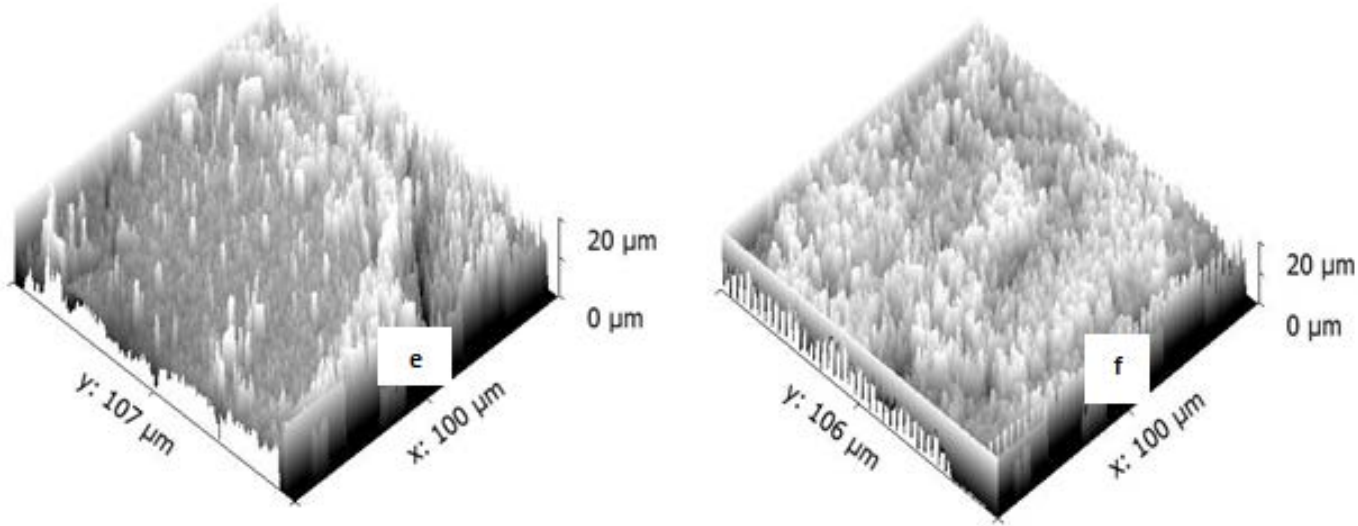

Figure 9. SEM Images of Laterite Based Material analyzed using Gwyddion Software (a) $0 \%$ bamboo fiber (b) $5 \%$ bamboo fiber (c) $10 \%$ bamboo fiber (d) $15 \%$ bamboo fiber (e) $20 \%$ bamboo fiber (f) $25 \%$ bamboo fiber.

\section{Conclusions}

The compressive strength of the bamboo fiber reinforced laterite (BFRL) block increased from $2.0 \pm 0.100$ to a maximum of $5.0 \pm 0.250 \mathrm{MPa}$ for 0 to $25 \%$ bamboo fiber addition. The sample with bamboo fiber of $25 \%$ has fracture toughness and flexural strength of $1.70 \pm 0.085 \mathrm{MPa} \sqrt{m}$ and $2.25 \pm 0.113 \mathrm{MPa}$ respectively. The comparison between the control and other samples with bamboo fiber showed that the presence of bamboo fiber in the matrix acted as crack arrester to the laterite based material.

Optical and SEM images of the bamboo fiber reinforced laterite block were studied and analyzed using Gwyddion software to study the fracture surface of the laterite based material, which showed brittle fracture surface for sample without fibers and ductile occurring in samples with fibers. EDS analysis showed trace element such as $\mathrm{Al}, \mathrm{Si}, \mathrm{Fe}, \mathrm{Ca}$ and $\mathrm{C}$.

The water absorption of the BFRL block showed that the minimum water absorption of $6 \%$ was obtained with samples without bamboo fiber and a maximum of $11.4 \%$ at $25 \%$ bamboo fiber addition. However, it still falls under the acceptable standard for conventional building blocks. The bulk density was also ascertained and it was noticed that as the weight percentage of bamboo fiber increased there was a decrease in the bulk density of the block.

Results obtained from this studies show that the bamboo fiber reinforced laterite block at weight percentage of $25 \%$ can be used as building block material, this work also provides a cheaper alternative to building block material by reduction in the use of cement for making of building blocks.

\section{Acknowledgements}

The authors would like to acknowledge the contributions of staffs of Department of Materials and Metallurgical Engineering, Federal University Oye-Ekiti, Ekiti State, Nigeria, staffs of Civil Engineering Department, Federal University of Technology Akure, Ondo State, Nigeria and finally Mr. Olanrewaju Gabriel of Covenant University, Otta, Ogun State, Nigeria.

\section{REFERENCES}

[1] Ferguson, C. (2007), Historical Introduction to the Development of Materials Science and Engineering as a Teaching Discipline, UK Centre for Materials Education, Liverpool, England., 1 - 27.

[2] Kavas, K. R. (2012), Structural Patterns Identified Through a Historical Analysis of Anatolian Stone Constructions, Scientific Research and Essays, 7(30), 2678-2690. DOI: 10.5897/SRE11.1135.

[3] Deplazes, A. (2005), Constructing Architecture Materials Processes Structures: A Handbook, Birkhäuser - Publishers for Architecture, Basel, Switzerland, 1-479.

[4] Rousseau, D., Environmental Friendly Building Materials, Sustainable Built Environment - Volume 1, Encyclopedia of Life Support System, 162 - 185.

[5] United Nations Environment Programme, (2009), Buildings and Climate Change, Sustainable Buildings \& Climate Initiative, 1 - 56 .

[6] Danso, H. (2013), Building Houses with Locally Available Materials in Ghana: Benefits and Problems, International Journal of Science and Technology, 2 (2), 225 - 231.

[7] Adedeji, Y. M. D, Fa, G. (2011), Sustainable housing provision: preference for the use of interlocking masonry in housing delivery in Nigeria, E3 Journal of Environmental Research and Management 3(1), 009-016.

[8] Meyer, C. (2002), Concrete and Sustainable Development, Special Publication American Concrete Institute, 206, 1 - 12.

[9] Makinde, O. O. (2012), Ecological and Sustainability Issues in Earth Construction, IOSR Journal of Environmental Science, Toxicology and Food Technology, 1(4), 20 - 28.

[10] Otoko, G. R. (2014), The Use of Laterites for Production of Soil-Cement Blocks, International Journal of Engineering and Technology Research, 2(4), 1 - 11. 
[11] Aguwa J. I. (2013), Study of Coir Reinforced Laterite Blocks for Buildings, Journal of Civil Engineering and Construction Technology, 4(4), 110 - 115.

[12] Kolawole, F.O., Adeniji, S. A.,Idowu, A. T., Owoseni, T. A., Ngasoh, O. F., Soboyejo, W.O. (2014), Corrugated Laterite Based Ceramic Roof Tile Stabilized with Cement, International Journal of Engineering and Technology, 4(3), $145-149$.

[13] Ogunbiyi, M. A., Samson R. A., Oginni, F. A., Akerele, E. (2014), Comparative Study of Cement Stabilized Clay Brick and Sandcrete Block as a Building Component, International Journal of Applied Science and Technology, 4(6), 56 - 61.

[14] Abbass, S. Z., Ali, S. S., Khattak, J. Z. K., Anwar, Z. (2103), Clean Development Mechanism: Laterite as Supplementary Cementing Material (SCM) to Reduce Greenhouse Gas Emissions (GHGs), Research Journal of Applied Sciences, Engineering and Technology 5(6): 2270-2277.

[15] Ogundalu, A. O., Adeboje, A. O., Adelaja, F. (2014), Effects of Soldier-Ant Mound (SAM) on the Strength Characteristics of Lateritic Clay Soils, British Journal of Applied Science \& Technology, 4(10): 1554-1565.

[16] Satpudke, D. S., Ashutkar, P. (2016), Case Study for Use of Laterite as Additive in Kilns for Cement Manufacturing, International Journal on Recent and Innovation Trends in Computing and Communication, 4(1), 213 - 215.

[17] Ukpata, J. O., Ephraim, M. E. (2012), Flexural and Tensile Strength Properties of Concrete Using Lateritic Sand and Quarry Dust as Fine Aggregate, ARPN Journal of Engineering and Applied Sciences, 7(3), 324 - 331.

[18] Sabarish, G., Ratnam, M. K. M. V., Prasad, A. C. S. V., Raju, U. R. (2015), A Study on Strength and Durability Characteristics of Concrete with Partial Replacement of Fine Aggregate by Laterite Sand, -International Journal for Innovative Research in Science \& Technology, 2(3), 134 141.

[19] Kalu, I. E., Jossou, E. E., Jacob, F., Ilboudo, A. I., Adedeji, A. F., Soboyejo, W. O. (2015), Polymer Reinforced Laterite for Building Materials, International Journal of Engineering and Technology, 5(2), 87 - 94.
[20] Awoyera, P. O., Akinwumi, I. I. (2014), Compressive Strength Development for Cement, Lime and Termite-hill Stabilised Lateritic Bricks, The International Journal of Engineering and Science, 3(2), $37-43$.

[21] Utodio N. F., Ekandem E. S., Egege C. C., Ocholi M., Atakpu O.D., Nwaigwe D.N. (2015), Investigation of the Effect of Bamboo Leaf Ash Blended Cement on Engineering Properties of Lateritic Blocks, Journal of Sustainable Development Studies, 8(1), 193-208.

[22] Oyekan, G. L., Kamiyo, O. M. (2011), A Study on the Engineering Properties of Sandcrete Blocks Produced with Rice Husk Ash Blended Cement, Journal of Engineering and Technology Research, 3(3), 88-98.

[23] Amada, S. (1997), Bamboo-A Natural, Super-Advanced and Intelligent Material. In: Proc 2nd Int Conference on Non-Conventional Construction Materials (NOCMAT-97), Bhubaneswar, India, 1-9.

[24] Das, M., Chakraborty, D. (2009), Effects of Alkalization and Fiber Loading On the Mechanical Properties and Morphology of Bamboo Fiber Composites in Resolution Matrix, Journal of Applied Polymer Science, 112(1), 447-453.

[25] Ghavami, K., Hombeeck, R.V. (2005), Application of Bamboo as a Construction Material: Part I-Mechanical Properties and Water-repellent Treatment of Bamboo, Part II-Bamboo Reinforced Concrete Beams. In: Proceeding of Latin American Symposium on Rational Organization of Building Applied to Low Cost Housing, CIB, Sa o Paulo, Brazil, 4966.

[26] Okubo, K., Fujii, T., Yamamoto, Y. (2004), Development of Bamboo-Based Polymer Composites and Their Mechanical Properties, Composites Part A: Applied Science and Manufacturing, 35(3), 377-383.

[27] Morel, J., Pkla, A., Walker, P. (2007), Compressive Strength Testing of Compressed Earth Blocks, Construction and Building Materials, $21 \quad$ (2), 303-309. DOI:10.1016/j.conbuildmat.2005.08.021

[28] Kabiru, M. (2010), Strength and Fracture of Earth-based and Natural Fiber-reinforced Composite, M.Sc. Thesis, African University of Science and Technology, Abuja, Nigeria. 